\title{
Indication of hydrocarbon migration in the Western Mecsek Mountains evidenced by fluid inclusion chemostratigraphy
}

\author{
KöRMÖs, Sándor ${ }^{1}$, LuKOCZKI, Georgina² ${ }^{2}$ SCHuBERT, Félix ${ }^{3}$ \\ ${ }^{1,3}$ University of Szeged, Department of Mineralogy, Geochemistry and Petrology, H-6722 Szeged, Egyetem u. 2. \\ ${ }^{2}$ University of Kentucky, Kentucky Geological Survey, 504 Rose Street, Lexington, KY 40502 \\ 1corresponding author, sandor.kormos@geo.u-szeged.hu, https://orcid.org/0000-0003-4439-6804 \\ ${ }^{2}$ gina.lukoczki@uky.edu, https://orcid.org/0000-0002-0661-0198 \\ ${ }^{3}$ schubert@geo.u-szeged.hu, https://orcid.org/0000-0001-8647-5354
}

\begin{abstract}
Primary and secondary hydrocarbon-bearing fluid inclusion (HCFI) assemblages occur in the Middle Triassic Lapis Limestone in the Szuadó Valley of the Western Mecsek Mts. The primary HCFIs were trapped in saddle dolomite crystals, and the secondary HCFIs were enclosed in calcite neospar and fracture-filling calcite. Solid bitumen is also present along fractures. The volatile compounds liberated from fluid inclusions are characterized by non-hydrocarbon and hydrocarbon species. The fluorescent properties of HCFIs, the occurrence of the solid bitumen, as well as the composition of inclusion oils indicate the migration of light oils through the Lapis Limestone. Petrographic observations suggest a prolonged oil charge event, which resulted in HCFIs beeing trapped under evolving diagenetic conditions.
\end{abstract}

Keywords: fluid inclusion chemostratigraphy, Lapis Limestone, Mecsek Mountains, petroleum inclusions, solid bitumen

\section{Introduction}

Hydrocarbon (HC) exploration has taken place in Southern Transdanubia since the 1930s. The first major HC reservoir along the Drava Basin was discovered in the 1950s. Since then, geological research focusing on petroleum has expanded to areas towards the Mecsek Mts. Nowadays, several oil companies are involved in the exploration, development and setting-up of hydrocarbon fields in order to boost production in the area of SSW Mecsek Mts. (SELMECZI 2018).

In Southern Transdanubia, Mesozoic and Cenozoic rocks have long been known to contain sufficient amounts of organic matter that had reached the oil window in some parts of the area. Therefore, such rocks can be considered as potential source rocks for the production of hydrocarbons (BADICS \& Vetó 2012, Selmeczi 2018). There are no commercial HC reservoirs in the Mecsek Mts.; however, traces of HC migration can be followed in outcrops in the Central and Eastern Mecsek Mts. (LuKOCZKI \& SCHuberT 2014). In general, the presence of HCs is usually indicated by fluid inclusions (FI) trapped in healed vacuoles within (cement) crystals, by tightly-held fluids in nano-pores, or by confined pores/spaces in and between other components of a rock. In the Mecsek Mts., near Pécsvárad, the Hosszúhetény Calcareous Marl hosts hydrocarbon-bearing fluid inclusions (HCFI) in fracture-filling calcite (LUKOCZKI et al 2012). BERÉNYI (2017) described HCFIs in fracture-filling calcite and euhedral quartz crystals in the partings of Mecsek Coal at Pécs-Vasas. LuKoczKi \& SchuberT (2014) reported HCFIs in planar-s dolomite crystals, in fracturefilling calcite, and in void-filling saddle dolomite and euhedral quartz crystals in the Middle Triassic dolostones at Árpádtetô. Towards the west, near the Kantavár quarry, SZIGETI (2013) documented HCFIs in fracture-filling calcite (Figure $1 a, b$ ). Up until now indications of $\mathrm{HC}$ migration in the Western Mecsek Mts have not been documented. However, a characteristic petroleum odour can be observed in the Western Mecsek Mts. while breaking debris of the Middle Triassic Lapis Limestone in the Szuadó Valley.

Fluid inclusion chemostratigraphy ( $\mathrm{FiCs}$ ) is used to characterize ancient diagenetic fluid systems. This method is based on a procedure that is called FIS (Fluid Inclusion Stratigraphy) or FIV (Fluid Inclusion Volatiles; VOLK \& GEORGE 2019). With FiCs the bulk of the respective organic and inorganic volatile compounds from FIs and other tightly-held fluids can be analysed. The results provide essential information for the documentation of $\mathrm{HC}$ paleoaccumulation, migration, or reservoir compartmentalization (VOLK \& GEORGE 2019).

The objective of this study was to determine the origin of 

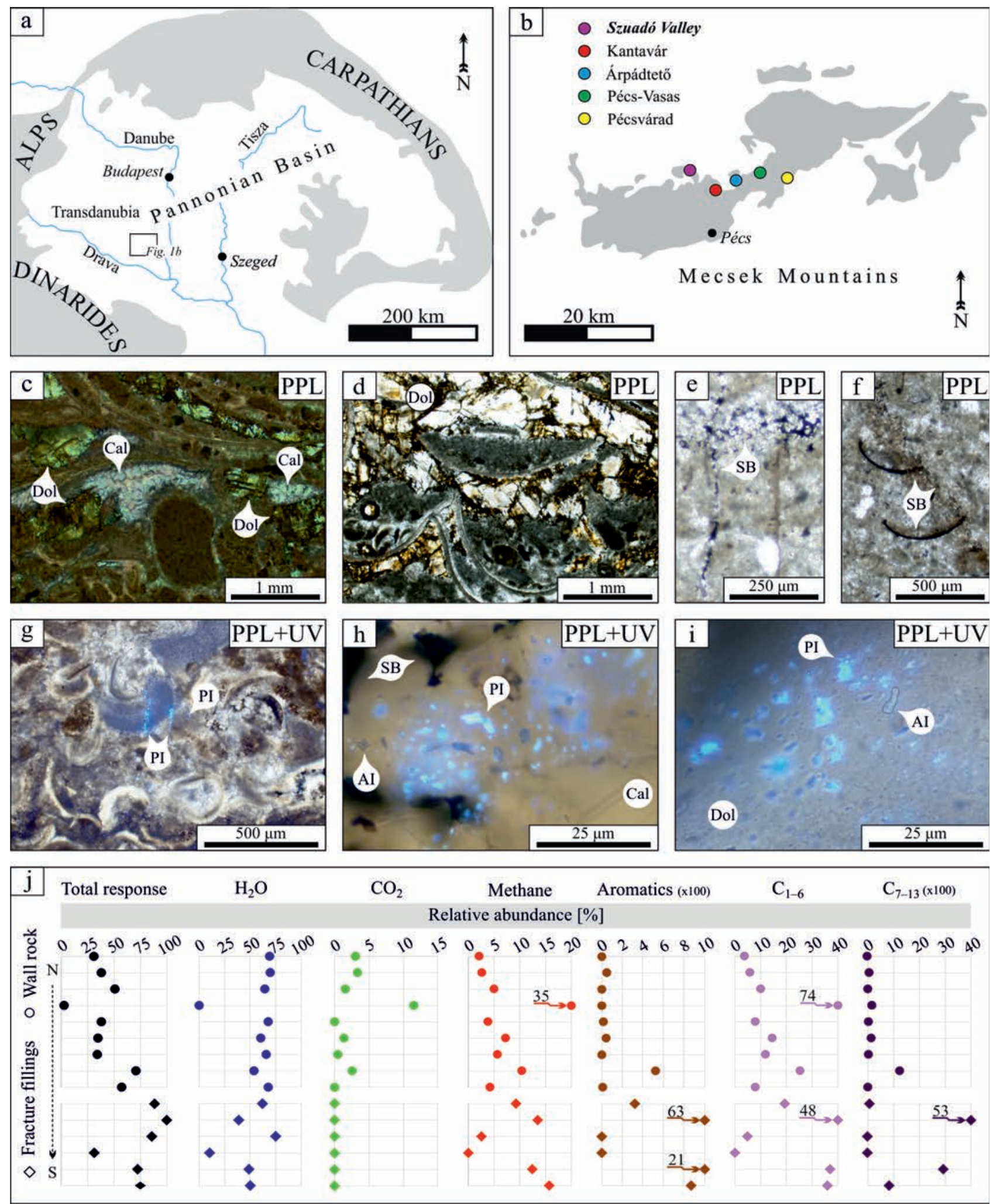

Figure 1. a) and b) Location of the study area and the sites of the previously published petroleum inclusion-bearing formations in the Mecsek Mountains (modified after LUKOCZKI \& SCHUBERT 2014). c) Packstone. Nonplanar (saddle) replacive dolomite (Dol), and equant, purple-stained calcite (Cal) in sheltered pores, stained thin section. Plane-polarized light (PPL). d) Packstone. Nonplanar (saddle) replacive dolomite (Dol) among skeletal grains filled with sediment. Plane-polarized light (PPL). e) Bedding-parallel and perpendicular fractures filled by calcite and solid bitumen (SB). Plane-polarized light. f) Solid bitumen filled fractures and skeletal grains. Plane-polarized light (PPL). g) Trails of secondary petroleum inclusions (PI) crosscutting several grains in neomorphic bioclastic packstone. Planepolarized light and UV excitation (PPL+UV). h) Primary petroleum (PI) and aqueous inclusions (AI) in granular fracture-filling calcite (Cal) and intercrystalline pore-filling solid bitumen (SB). Planepolarized light and UV excitation (PPL+UV). i) Primary petroleum (PI) and aqueous inclusions (AI) in the nonplanar (saddle) dolomite (Dol). Plane-polarized light and UV excitation (PPL+UV).j) Fluid inclusion chemostratigraphy log of the studied fracture fillings and wall rock samples along the Szuadó Valley. The samples on the vertical axes are ordered according to their location to the south along the valley 
the petroleum odour of the Lapis Limestone in the Szuadó Valley using micropetrography and FiCs. The results obtained revealed that the detected hydrocarbon signal (i.e., the petroleum odour) is caused by remnants of natural HCbearing fluids that once migrated through the area.

\section{Samples and analytical methods}

Nine samples from the debris of the Lapis Limestone, which is characterised by petroleum odour, were collected along the Szuadó Valley. A representative sample was selected and stained to distinguish calcite, Fe-calcite, dolomite, Fe-dolomite/ankerite, using the method of DiCKSON (1966). Detailed micropetrography was prepared using an Olympus BX41 polarization microscope. A Reliotron VII cathodoluminescence (CL) device assembled on an Olympus BX63 polarising microscope was applied for CL microscopy. UV-fluorescence microscopy was used to characterize the HCFIs. The Olympus BX41 polarization microscope was used for the analysis. It was equipped with a $100 \mathrm{~W}$ high-pressure $\mathrm{Hg}$ lamp and an Olympus U-MNU-2 filter set for blue-violet (400-440 nm) and ultraviolet (360 $370 \mathrm{~nm}$ ) excitation. Terms and symbols suggested by DiAmOND (2003) were employed in this study for the FI analysis. The volume fractions of the vapour phases $\left(\varphi_{\mathrm{V}}\right)$ were estimated at room temperature. The petroleum odour was inspected with FiCs analysis that involved mass spectrometry without chromatographic pre-separation. The analytical workflow was based on KöRMÖs et al. (2017), and it included the following steps: fracture-filling calcite and sidewall limestone were separated under a stereomicroscope, and they were then cleaned rigorously in an ultrasonic bath using rea-sol detergent. The bulk samples together with internal standards were loaded and crushed in a vacuum-pneumatic crushing chamber at $100{ }^{\circ} \mathrm{C}$. The liberated volatile compounds were electron ionized and swept into a quadrupole PFEIFFER PrismaPlus ${ }^{\mathrm{TM}}$ QMG 220 mass spectrometer. The molecular species were analysed in scanning mode by an electron multiplier according to their mass-to-charge ratio $(\mathrm{m} / \mathrm{z})$ in the range of $\mathrm{m} / \mathrm{z} 2-180$. The obtained non-hydrocarbon and hydrocarbon species were normalized against the total response of each sample. Moreover, to make the signals comparable between the individual samples the total response was normalized against the maximum reading.

\section{Results and discussion}

The analysed Lapis Limestone sample is made up of $<3$ $\mathrm{mm}$-thick layers of various limestone microfacies, including bioclastic-peloidal wackestones and packstones (Figure 1c, $d$ ). Microscale gradation and bedding are highlighted by differences in the grain-size and matrix content. The packstones consist of peloids and bioclasts, and the matrix has been replaced by non-ferroan neomorphic sparry calcite.
The bioclasts include ostracods, crinoids, echinoderms, gastropods and foraminifers. Some bioclasts and peloids are marked by micritic envelopes. In a few cases, the skeletal grains have been replaced by non-ferroan calcite. These calcite crystals show bright orange CL colour, mimicking the precursor bioclasts. The vug pores contain partially ferroan calcite neospar (Figure 1c). Locally, medium to coarse crystalline nonplanar (saddle) dolomite (30 to $500 \mu \mathrm{m})$ appears to to preferentially replace the calcite neospar (Figure 1c, $d$ ). This replacive saddle dolomite is non-ferroan and exhibits non-luminescent CL signal. Spots and patches of iron oxyhydroxides are distributed unevenly throughout the sample and are especially associated with the saddle dolomite where (locally) they cause brownish colouration of the dolomite (Figure 1c, d). Micro-stylolites occur in the sample, and branching fractures intersect the limestone. These fractures are filled with equant granular, non-ferroan calcite that exhibits a dull orange CL colour. Solid bitumen is, where present, the final phase filling fractures and moldic pores after skeletal grains adjacent to the bitumen-filled fractures (Figure $1 e, f$ ). The fractures, containing bitumen, locally touch and cease in microstylolites, but the healed fractures crosscut the latter without any sign of solid bitumen.

The HCFIs are present in matrix and skeletal grain replacive non-ferroan neospar and fracture-filling calcite, as well as in the replacive nonplanar (saddle) dolomite (Figure $1 g, h$ and $i)$. The petroleum inclusions are colourless and locally brownish in plane-polarized light, and they show a uniform blue fluorescent colour under UV excitation (Figure $1 g, h$ and $i$ ). The inclusions are characterised by their irregular shape and range in size up to $10 \mu \mathrm{m}$.

In the non-ferroan neospar calcite, HCFIs take the form of a few mm-long trails, which crosscut several crystals and grains, suggesting a secondary origin (Figure $1 g$ ). There are one-phase, liquid hydrocarbon $\left(\mathrm{L}_{\mathrm{hc}}\right)$ and two-phase liquiddominant, liquid and gas hydrocarbon inclusions $\left(\mathrm{L}_{\mathrm{hc}}+\mathrm{V}\right.$; $\left.\varphi_{\mathrm{V}}: 0.2-0.3\right)$. Spatially rare cogenetic, two-phase liquiddominant, aqueous FIs $\left(\mathrm{L}_{\mathrm{aq}}+\mathrm{V} ; \varphi_{\mathrm{v}}: 0.1-0.2\right)$ also occur within fluid inclusion assemblages (FIA).

HCFIs are present in the fracture-filling calcite. The crystals, that host the HCFIs are associated with solid bitumen that fills fractures (Figure $1 h$ ). The FIs are present as one-phase $\left(\mathrm{L}_{\mathrm{hc}}\right)$ and two-phase liquid-dominant $\left(\mathrm{L}_{\mathrm{hc}}+\mathrm{V} ; \varphi_{\mathrm{v}}: 0.2-0.3\right)$, as well as spatially rare cogenetic, two-phase liquid-dominant aqueous inclusions $\left(\mathrm{L}_{\mathrm{aq}}+\mathrm{V} ; \varphi_{\mathrm{V}}: 0.2-0.3\right)$. The FIAs can be followed in trails along the solid bitumen-filled fractures, suggesting secondary origin. The solid bitumen is characterized by black and brownish colouring in plane-polarized light depending on the thickness of the secondary macerals.

The dolomite hosted FIs are one- $\left(\mathrm{L}_{\mathrm{hc}}\right)$, two- $\left(\mathrm{L}_{\mathrm{hc}}+\mathrm{V} ; \varphi_{\mathrm{V}}\right.$ : 0.1-0.3), and three-phase $\left(\mathrm{L}_{\mathrm{aq}}+\mathrm{L}_{\mathrm{hc}}+\mathrm{V}\right)$ liquid-dominant HCFIs with locally co-occurring two-phase liquid-dominant $\left(\mathrm{L}_{\mathrm{aq}}+\mathrm{V} ; \varphi_{\mathrm{V}}: 0.2-0.3\right)$ aqueous FIs. They occur in the core of the crystals and along growth zones, suggesting a primary origin (Figure 1i).

Based on FiCs, the investigated samples contain the fol- 
lowing inorganic and organic compounds (Figure $1 j$ ): Higher amounts of volatiles were liberated from the fracture-filling calcites relative to the wall rock samples. The non-hydrocarbon species, especially $\mathrm{H}_{2} \mathrm{O}$ and $\mathrm{CO}_{2}$, dominate in the obtained mass spectra of wall rock samples. In contrast, $\mathrm{CO}_{2}$ is absent in the fracture-filling calcite. HCs were present in all analysed samples, gaseous $\mathrm{HC}$ species $\left(\mathrm{C}_{1-6}\right)$, notably methane, predominate the $\mathrm{HC}$ fraction. Beside the methane, HCs containing up to six carbon atoms were also present in all samples. The abundance of aromatic hydrocarbons, such as benzene, toluene and xylene, as well as of heavier organic compounds, containing a maximum 13 carbon atoms is lower than the total amount of $\mathrm{C}_{1-6}$. The contribution of $\mathrm{HCs}$ to the total response is highly variable. There are samples in which the amounts of heavier HCs containing more than six carbon atoms are negligible.

The presence of solid bitumen, UV-fluorescent (i.e., hydrocarbon-bearing) fluid inclusions and the geochemical signature of the volatile compounds liberated from the samples indicate ancient HC migration through the Lapis Limestone in the Szuadó Valley. The uniform blue fluorescent colour of the HCFIs, the presence of the solid bitumen and the composition of the inclusion oils in all studied samples probably represent light oils trapped in fluid inclusions (cf., VOLK \& GEORGE 2019). Oil migration probably persisted over a prolonged period and this allowed HCFIs to be trapped under evolving diagenetic conditions. This, in turn, presumably led to the observed variation in the composition of the liberated volatiles.

The Szuadó Valley represents the westernmost location in the Mecsek Mts., which is affected by the syn- or postTriassic HC migration. A detailed investigation of the diagenetic evolution of the Lapis Limestone, as well as thorough analysis of the cogenetic aqueous and $\mathrm{HC}$ fluid inclusions, are necessary to specify the physicochemical conditions of fluid migration and to accurately place the timing of $\mathrm{HC}$ emplacement in the diagenetic history.

\section{Acknowledgements}

The authors thank the editor-in-chief Orsolya SzTANó and the reviewers Orsolya GYŐRI and Zsolt BENKó for their constructive comments. This study was supported by NTPNFTÖ-19-B-0152.

\section{References}

BADICS, B. \& VETŐ, I. 2012: Source rocks and petroleum systems in the Hungarian part of the Pannonian Basin: The potential for shale gas and shale oil plays. - Marine and Petroleum Geology 31, 53-69. https://doi.org/10.1016/j.marpetgeo.2011.08.015

BERÉNYI B. 2017: Szénhidrogén-migráció nyomai a pécs-vasasi külfejtésben (Mecsek hegység). - MSc Diplomadolgozat, SZTE Ásványtani, Geokémiai és Kőzettani Tanszék, Szeged, 62 p.

DiAmond, W. L. 2003: Glossary: Terms and symbols used in fluid inclusion studies. - In: SAMson, I., Anderson, A. \& MARshaLL, D. (szerk.): Fluid inclusions: analysis and interpretation. - MAC Short course series 32, 363-372.

DiCKSON, J. 1966: Carbonate identification and genesis as revealed by staining. - Journal of Sedimentary Research 36, 491-505. https://doi:10.1306/74d714f6-2b21-11d7-8648000102c1865d

KöRMÖs S., CZIRBUS N., \& SCHUBERT F. 2017: Furadékminták gáz és illékony komponenseinek vizsgálatához szükséges minta-előkészítési és -feltárási protokoll fejlesztésének eredményei. - Földtani Közlöny 147, 399-414. https://doi.org/10.23928/foldt.kozl. 2017.147.4.399

LUKOCZKI, G. \& SChUBeRT, F. 2014: Traces of hydrocarbon migration in the Central Mecsek Mountains. - Földtani Közlöny 144, $403-407$.

LuKoczki G., Schubert F. \& HÁMORNÉ Vidó M. 2012: Szénhidrogén-migráció nyomai Pécsvárad környékén (Mecsek hegység). Földtani Közlöny 142, 229-242.

SELMECZI I. 2018: Magyarország szénhidrogén-kutatási területei - Dél-Dunántúl - Zala- és Dráva-medence. - In: KovÁcs Zs. (szerk.): Szénhidrogének Magyarországon. - MEKH kiadvány, Budapest, 51-77.

SzIGETI M. 2013: A Kantavári Formáció szénhidrogén-tartalmú kalcitereinek petrográfiai vizsgálata. - BSc Szakdolgozat, SZTE Ásványtani, Geokémiai és Kőzettani Tanszék, Szeged, 42 p.

Volk, H. \& George, S. C. 2019. Using petroleum inclusions to trace petroleum systems - A review. - Organic Geochemistry 129, 99 123. https://doi:10.1016/j.orggeochem.2019.01.012

Manuscript recieved: 04/03/2020 